\title{
Heart rate as a predictor of ketamine's fast-acting antidepressant response
}

Citation for published version (APA):

Arns, M., \& van Dijk, H. (2021). Heart rate as a predictor of ketamine's fast-acting antidepressant response. Clinical Neurophysiology, 132(6), 1330-1331. https://doi.org/10.1016/j.clinph.2021.03.011

Document status and date:

Published: 01/06/2021

DOI:

10.1016/j.clinph.2021.03.011

Document Version:

Publisher's PDF, also known as Version of record

Document license:

Taverne

Please check the document version of this publication:

- A submitted manuscript is the version of the article upon submission and before peer-review. There can be important differences between the submitted version and the official published version of record.

People interested in the research are advised to contact the author for the final version of the publication, or visit the DOI to the publisher's website.

- The final author version and the galley proof are versions of the publication after peer review.

- The final published version features the final layout of the paper including the volume, issue and page numbers.

Link to publication

\footnotetext{
General rights rights.

- You may freely distribute the URL identifying the publication in the public portal. please follow below link for the End User Agreement:

www.umlib.nl/taverne-license

Take down policy

If you believe that this document breaches copyright please contact us at:

repository@maastrichtuniversity.nl

providing details and we will investigate your claim.
}

Copyright and moral rights for the publications made accessible in the public portal are retained by the authors and/or other copyright owners and it is a condition of accessing publications that users recognise and abide by the legal requirements associated with these

- Users may download and print one copy of any publication from the public portal for the purpose of private study or research.

- You may not further distribute the material or use it for any profit-making activity or commercial gain

If the publication is distributed under the terms of Article $25 \mathrm{fa}$ of the Dutch Copyright Act, indicated by the "Taverne" license above, 
Editorial

\section{Heart rate as a predictor of ketamine's fast-acting antidepressant response}

See Article, pages 1339-1346

It has been two decades since the first publication on the antidepressant effects of the glutaminergic drug ketamine appeared (Berman et al., 2000). This heralded the era of fast-acting antidepressants discarding the old belief that antidepressant treatments simply needed 6-8 weeks to take effect. Since this early report, many other fast-acting antidepressants have been described such as nitric oxide (glutamatergic), scopolamine (antimuscarinic agent) and accelerated prefrontal rTMS protocols. Historically, however, the first indication for a role of glutamatergic drugs with rapid effects in depression originate from 1959 when it was observed that D-cycloserine (a tuberculosis antibiotic) caused rather rapid mood improvement in 30 of 37 patients, a finding that was soon after replicated (reviewed in Krystal et al., 2013). Another well-known fast-acting 'antidepressant' was first described around that same time, namely sleep deprivation therapy (SDT), which also results in immediate alleviation of depressive symptoms in about $40-60 \%$ of patients (Bunney and Bunney, 2012), albeit depressive symptoms often reappear after the first recovery sleep.

Next to the more conventionally used selective serotonin reuptake inhibitor (SSRI), or selective serotonin and noradrenalin reuptake inhibitor (SNRI) antidepressant treatments, this means an extension of the family of antidepressant treatments, with quite different mechanisms of action. However, how to decide what treatment a given patient would benefit from the most? Given the current 'stepped care' approach, often utilized due to lacking objective biomarkers to base a treatment choice on, the study by Meyer and colleagues in this issue of Clinical Neurophysiology is an important step in the right direction. Meyer and colleagues used data from two clinical trials that investigated the efficacy of ketamine in Major Depressive Disorder (MDD), where they investigated how baseline heart rate (HR) and heart rate variability (HRV) were associated with clinical response. It is known that the acute effects of ketamine result in increasing sympathetic tone, which they confirmed by higher HR and lower HRV after 30 and 60 min of ketamine infusion. Furthermore, plasma ketamine and norketamine levels were significantly associated with HR and HRV changes, confirming the direct sympathetic action (and maybe disengagement of the parasympathetic system) of ketamine. Therefore, ketamine is among the many antidepressant treatments that has been shown to have an impact on autonomic parameters such as HR and HRV.
However, could it be that, rather than simply viewing this as a non-specific drug 'side effect', baseline autonomic function or reactivity of the autonomic nervous system (ANS) could carry more important information related to MDD relevant functional networks? For example, it is known that from a bottom-up perspective, vagal nerve stimulation exerts antidepressant effects and, from a top-down perspective, pre-frontal rTMS and tDCS result in parasympathetic activation, highlighting activation of the frontalvagal pathway involved in MDD (see Fig. 1, also reviewed in Iseger et al., 2020). Therefore, a relatively 'simple' psychophysiological measure such as HR and HRV could reflect engagement or disengagement of this frontal vagal network (without the need for an fMRI), and possibly inform treatment decisions. That - most interestingly - was exactly what Meyer and colleagues found; higher baseline HR was associated with better clinical response to ketamine as assessed the next day with a medium effect size of $d=0.61$ (albeit only for partial response using a 30\% cut-off). In prior work, Olbrich and colleagues already described that dynamic changes of ANS arousal were specifically associated with response to the SNRI Venlafaxine, while no such effect was observed for SSRIs (Olbrich et al., 2016). Thus, ANS measures might become instrumental in future precision or stratified treatment strategies in psychiatry. Further systematic validation of differential ANS measures for a wider range of antidepressant would thus be an important step, and likely, such data is already available from safety measures (e.g. ECG recorded in clinical trials) or EEG/ECG recordings, but largely overlooked in many studies.

While the pharmacological mode of action between some of the above described fast-acting antidepressants are rather different (e.g., ketamine as a glutamatergic agent vs. scopolamine as an antimuscarinic agent), behaviorally they do seem to have in common that they are all highly 'sedating' (ketamine in higher doses is an anesthetic; scopolamine often causing drowsiness and sleepiness), and essentially a similar 'sedating state' is induced by sleep deprivation. This association between sleep deprivation and the rapid antidepressant effects of ketamine has been illuminated recently in more detail as well, where common gene expression patterns between SDT and ketamine have been reported and sensitivity to the antidepressant effects of ketamine was related to circadian factors (see: Morgan, 2017), suggesting possible overlap between several of these fast-acting antidepressants. In their dis- 


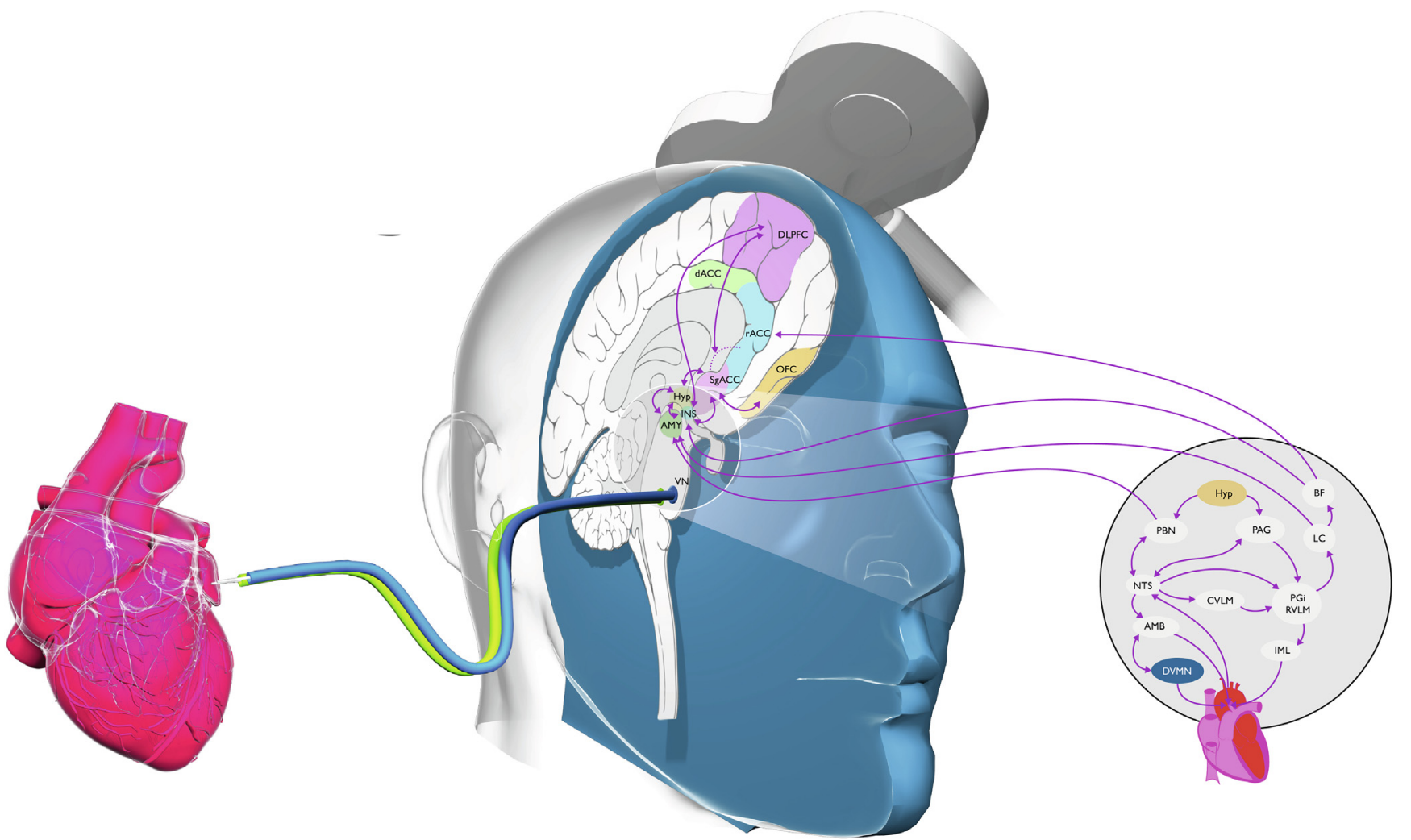

Fig. 1. Depicting the frontal-vagal pathway comprising the Dorsolateral Prefrontal Cortex (DLPFC), subgenual anterior cingulate cortex (sgACC), vagal nerve and other structures (reviewed in: Iseger et al., 2020).

cussion, Meyer and colleagues also draw upon the parallels between these fast-acting antidepressants and a possible shared mechanism related to vigilance/drowsiness or sleep pressure, which makes one wonder if the same lessons learned from extending the effects of SDT using chronotherapy (sleep phase advance and light therapy; e.g., see: Bunney and Bunney, 2012), would also aid in extending the antidepressant effects of ketamine and other fast acting antidepressants? All-in-all, an exciting future awaits of more targeted treatment options where psychophysiology is likely to play an important role.

\section{Declaration of Competing Interest}

The authors declare that they have no known competing financial interests or personal relationships that could have appeared to influence the work reported in this paper.

\section{References}

Berman RM, Cappiello A, Anand A, Oren DA, Heninger GR, Charney DS, Krystal JH. Antidepressant effects of ketamine in depressed patients. Biol Psychiatry 2000;47(4):351-4. https://doi.org/10.1016/S0006-3223(99)00230-9.

Bunney BG, Bunney WE. Rapid-acting antidepressant strategies: mechanisms of action. Int J Neuropsychopharmacol 2012;15(05):695-713. https://doi.org/ $10.1017 /$ S1461145711000927.

Iseger TA, van Bueren NER, Kenemans JL, Gevirtz R, Arns M. A frontal-vagal network theory for major depressive disorder: Implications for optimizing neuromodulation techniques. Brain Stimul 2020;13(1):1-9. https://doi.org/ 10.1016/i.brs.2019.10.006

Krystal JH, Sanacora G, Duman RS. Rapid-acting glutamatergic antidepressants: The path to ketamine and beyond. Biol Psychiatry 2013;73(12):1133-41. https:// doi.org/10.1016/i.biopsych.2013.03.026.
Meyer T, Brunovsky M, Horacek J, Novak T, Andrashko V, Seifritz E, et al. Predictive value of heart rate in treatment of major depression with ketamine in two controlled trials. Clin Neurophysiol 2021;132(6):1339-46.

Morgan PT. Ketamine and sleep: bridging the gap in the treatment of depressive illness. Biol Psychiatry 2017;82(5):309-11. https://doi.org/10.1016/i. biopsych.2017.07.005.

Olbrich S, Tränkner A, Surova G, Gevirtz R, Gordon E, Hegerl U, Arns M. CNS- and ANS-arousal predict response to antidepressant medication: Findings from the randomized iSPOT-D study. J Psychiatr Res 2016;73:108-15. https://doi.org/ 10.1016/i.jpsychires.2015.12.001.

Martijn Arns*

Research Institute Brainclinics, Brainclinics Foundation, Nijmegen, the

Netherlands

Department of Psychiatry, Amsterdam UMC, University of Amsterdam, Location AMC, Amsterdam Neuroscience, the Netherlands

Department of Cognitive Neuroscience, Faculty of Psychology and Neuroscience, Maastricht University, Maastricht, the Netherlands

* Corresponding author at: Research Institute Brainclinics, Brainclinics Foundation, Bijleveldsingel 34, 6524 AD Nijmegen, the Netherlands.

E-mail address: martijn@brainclinics.com

Hanneke van Dijk

Research Institute Brainclinics, Brainclinics Foundation, Nijmegen, the Netherlands

Department of Psychiatry, Amsterdam UMC, University of Amsterdam, Location AMC, Amsterdam Neuroscience, the Netherlands Accepted 18 March 2021

Available online 29 March 2021 